\title{
Naturalized alien flora of the Indian states: biogeographic patterns, taxonomic structure and drivers of species richness
}

\author{
Inderjit $(\mathbb{D} \cdot$ Jan Pergl $\cdot$ Mark van Kleunen $(\mathbb{D} \cdot$ Martin Hejda Cherukuri Raghavendra Babu • \\ Sudipto Majumdar • Paramjit Singh · Surendra Pratap Singh • Sugali Salamma • \\ Boyina Ravi Prasad Rao $\cdot$ Petr Pyšek (D)
}

\begin{abstract}
Despite an existing India-wide inventory of alien plant species, an inventory documenting the occurrence of naturalized alien plant species in each of the Indian states (including union territories) was not available yet. We compiled from the literature a list of naturalized alien vascular plant species with data on their occurrence in 33 Indian states, and related the richness of naturalized species per state to climate, socioeconomic parameters and human influence. In total, we report 471 naturalized species in India, which
\end{abstract}

\section{Inderjit $(\bowtie) \cdot S$. Majumdar}

Department of Environmental Studies, Centre for

Environmental Management of Degraded Ecosystems

(CEMDE), University of Delhi, Delhi, India

e-mail: inderjitdu@gmail.com

J. Pergl - M. Hejda · P. Pyšek

Department of Invasion Ecology, Institute of Botany, The Czech Academy of Sciences, 25243 Průhonice, Czech Republic

\section{M. van Kleunen}

Department of Biology, University of Konstanz,

Universitätsstrasse 10, 78457 Constance, Germany

\section{M. van Kleunen}

Zhejiang Provincial Key Laboratory of Plant Evolutionary Ecology and Conservation, Taizhou University,

Taizhou 318000 , China represents $2.6 \%$ of the total flora of this country, and for 449 of them we provide the distribution in the states. The highest and lowest numbers of naturalized species are reported from Tamil Nadu (332) and the island Lakshadweep (17), respectively. The families richest in naturalized species are Compositae (75), Leguminosae (60) and Poaceae (36). The highest numbers of naturalized aliens occurs in states located at lower latitudes in the tropics, and in more northernly located states that even in the dry period still have relatively high amounts of precipitation. Naturalized species richness of a state is furthermore positively related to socioeconomic factors represented by the percentage of the population living in urban areas, and

\section{R. Babu}

Centre for Environmental Management of Degraded

Ecosystems (CEMDE), University of Delhi, Delhi, India

P. Singh

Botanical Survey of India, CGO Complex, Salt Lake City, Kolkata 700 064, India

\section{S. P. Singh}

Central Himalaya Environment Association (CHEA), 06 Waldorf Compound, Nainital, Uttarakhand 263001, India

S. Salamma · B. R. P. Rao

Department of Botany, Sri Krishnadevaraya University, Anantapuramu 515003, India

P. Pyšek

Department of Ecology, Faculty of Science, Charles University, Viničná 7, 12844 Prague, Czech Republic 
human population density. The state-wise inventory of naturalized alien species improves our knowledge on threats associated with plant invasions in India, and can be used to provide arguments for promoting programs on conservation of native biodiversity in the country as well as in particular states.

Keywords Exotic plants - Plant invasion · Naturalization - India - Species richness - Climate · Socioeconomic factors

\section{Introduction}

Invasion by alien plants (i.e. plant species introduced by humans to regions outside their native distribution; Richardson et al. 2000; Pyšek et al. 2004; Blackburn et al. 2011) is an important aspect of the Anthropocene (van Kleunen et al. 2015; Dawson et al. 2017; Pyšek et al. 2017). The situation is alarming because already more than 13,000 plant species (4\% of the extant global vascular flora) have become naturalized somewhere on the globe as a result of human activity (van Kleunen et al. 2015; Pyšek et al. 2017), and many of them represent a threat to biodiversity (Hulme 2009; Hulme et al. 2009; McGeoch et al. 2010; Early et al. 2016). Alien plants have invaded virtually all parts of the world but the numbers vary a lot among regions all around the globe (van Kleunen et al. 2015; Dawson et al. 2017; Pyšek et al. 2017). The greatest numbers of naturalized plant species are recorded for North America $(\sim 6000)$, and Europe $(\sim 4000)$, whereas the lowest numbers (after Antarctica; 160) are recorded for temperate Asia $(\sim 2200)$ and tropical Asia ( 2000 species) (van Kleunen et al. 2015). In Asia, however, there are many emerging economies where the numbers of alien naturalized species are predicted to increase considerably in the future (Seebens et al. 2015). Therefore, more detailed alien species inventories of these regions are needed.

Due to the widely documented impacts of invasive alien species on native biodiversity, ecosystem functioning and economy, as well as human health (Vilà et al. 2010, 2015; Pyšek et al. 2012b; Kumschick et al. 2015; Rumlerová et al. 2016), invasive alien species have long been recognized as a key component of global environmental change (Millenium Ecosystem Assessment 2005; Kettunen et al. 2009). However, only a small proportion of species introduced by humans establish and maintain populations without direct human aid (naturalized species sensu Richardson et al. 2000; Blackburn et al. 2011). Although only a subset naturalized species spread rapidly (i.e. become invasive), and even fewer have strong negative ecological and economic impacts (Blackburn et al. 2014), documenting which alien species have become naturalized is a prerequisite for better understanding the causes of plant invasions. Detailed lists of naturalized alien plants using a standardized classification started to appear in the 2000s and over the last decade became available for many countries, with most research concentrated in Europe (e.g. Essl and Rabitsch 2002; Pyšek et al. 2002, 2012a; Medvecká et al. 2012; see Lambdon et al. 2008 for overview of national checklists). A major improvement in this field occurred recently, with the compilation of such lists in the Global Naturalized Alien Flora (GloNAF) database (van Kleunen et al. 2015; Pyšek et al. 2017). While lists of naturalized species are available for some Asian countries such as China (Liu et al. 2006; Wu et al. 2010; Jiang et al. 2011), Singapore (Corlett 1992), Hong Kong (Corlett 1992), Sri Lanka (Iqbal et al. 2014), Nepal (Shrestha 2016) and Taiwan (Wu et al. 2003, 2004a, b; Wu and Wang 2005), large parts of Asia are still data-deficient (van Kleunen et al. 2015; Pyšek et al. 2017).

Prior to the compilation of the GloNAF database, one of the large Asian countries without a state-wise inventory of naturalized alien plants was India. There is, however, information available on the invasive alien species of India (Reddy et al. 2008; Bhatt et al. 2012), and Khuroo et al. (2012) published an account of 1599 alien plant species of India with data on their invasion status, native ranges, and families to which alien species belong. This India-wide inventory categorized the alien species according to whether they were cultivated, casual, naturalized or invasive, with separate categories 'casual or naturalized' and 'naturalized or invasive', where the status could not be assigned with certainty. Furthermore, although recently Adhikari et al. (2015) used ecological niche modelling to identify hotspots of invasive alien species, an empirical overview of where in India the alien species actually occur is lacking. There are, however, numerous reports on the presence of alien plant species in different states of India (see Electronic Supplementary Material 1) that could be used to make 
an inventory of naturalized species for each state and union territory.

The Republic of India has an area of 3.288 million $\mathrm{km}^{2}$ in an environmentally heterogeneous part of tropical Asia, and has 1.33 billion inhabitants (382 inhabitants per $\mathrm{km}^{2}$ ). India is likely to be prone to plant invasions due to several historical and geographical factors (IndianStat 2017). Many natural and humancreated migration routes opened possibilities for invasion by alien species, and long-lasting human influence, which diversified the already naturally heterogeneous landscape mosaic, created suitable habitats for alien species (Bogaert et al. 2014; Paschou et al. 2014). In India, there are 29 states and seven union territories, which vary widely in climate, size, human population density and socioeconomic aspects. These features, together with a high biodiversity and in-depth knowledge of plant communities make the country suitable for studying regional patterns of plant invasions.

Here, we provide, the first inventories of naturalized plant species of the Republic of India for each of its states. We explore the basic taxonomic composition and ecological characteristics of the naturalized alien flora, and analyze the main climatic, geographic and socioeconomic drivers of the regional richness of naturalized species.

\section{Methods}

State-wise inventory of naturalized species

To prepare an inventory of naturalized alien vascular plant species (following the definition of Richardson et al. 2000; Blackburn et al. 2011) for each of India's states and union territories (hereafter collectively referred to as states) with information about the origin, distribution and life form of the species, we consulted national and regional floras, e-floras, and research articles published in scientific journals (Electronic Supplementary Material 1). We chose different states and union territories of India (administrative units) rather than biogeographic units because most of the original data sources on naturalized species use administrative units. In addition, data on some of the potential drivers, such as gross domestic product (GDP) and human population density, are only available for administrative units. Alien species that are only cultivated and not naturalized in the wild were not included in the inventories.

We considered the current states of Andhra Pradesh and Telangana jointly as one region termed "Andhra Pradesh", because the two states separated only in 2014, and as a consequence most floristic and socioeconomic data do not distinguish between them. Furthermore, naturalized species of the union territories Dadra Nagar and Haveli, and Daman and Diu were combined with the state of Goa (Rao 1985). Therefore, our inventory has 33 instead of 36 states (i.e. 29 true states and 7 union territories), but covers the entire Republic of India.

As the different sources often use different names for one and the same species, we provide in this paper also a standardized taxonomy of the naturalized Indian flora according to "The Plant List" (http://www. theplantlist.org). Taxonomic standardization was done with the help of the Taxonstand package (Cayuela et al. 2017) in $\mathrm{R}$ ( $\mathrm{R}$ Core Team 2016). Taxonomic standardization also facilitated finding data on native ranges and life forms. In the Electronic Supplementary Material 2, we also provide the original names used in particular data sources.

Data on life-form and origin of species

Plant species identified as naturalized were assigned to the following life-form categories: annual/biennial herb, perennial herb, shrub, tree, aquatic plant, climber. Species were further classified according to their region of origin (native range); each was assigned to one or more of the major biogeographically defined areas (continents) of the Taxonomic Databases Working Group (TDWG; currently named Biodiversity Information Standards; Brummitt 2001). Species whose native range is unknown, as they are only known from cultivation, and species that originated through recent hybridization are listed as a separate category. Origin data were taken from the working database GloNAF (van Kleunen et al. 2015), and then validated by using local floras and online sources.

Environmental and socioeconomic data on Indian states

Data on climate (climate scores defined by Dupin et al. 2011), rural versus urban population size (IndianStat 
2017), total area $\left(\mathrm{km}^{2}\right)$, population density of Indian states (inhabitants $/ \mathrm{km}^{2}$ ), and GDP per capita (US\$; NITI Aayog 2015) was collected from various sources (Electronic Supplementary Material 1). The urban and rural population sizes were calculated from the percentages of the population living in cities (urban) and villages (rural). States were assigned to zonobiomes (see Pyšek et al. 2017 for details), and geographical coordinates (latitude and longitude) taken as those of the centroid of the state.

To describe and quantify the climate of the individual states, we used the 19 bioclimatic variables available through the WorldClim database (see http:// www.worldclim.org; Hijmans et al. 2005) to create three principal component axes (PCAs) that together explain nearly $85 \%$ of the variation present in the original 19 variables (following Dupin et al. 2011). The resulting PCAs represent three uncorrelated linear combinations of the original climate data, with the first one (PCA1) mainly representing mean annual temperature, the second one (PCA2) mainly representing precipitation during wet or warm periods, and the third one (PCA3) mainly representing precipitation during the driest period (Dupin et al. 2011).

\section{Statistical analysis}

To test whether there are differences in the numbers of naturalized species among the Indian states in terms of representation of species with different life histories and of different origins, their counts were analysed by row $\times$ column contingency tables, using generalized linear models with the log-link function and a Poisson error distribution (e.g. Crawley 1993). The adjusted standardized residuals of G-tests were compared with critical values of the normal distribution to assess which life-history category or region of origin is represented more or less than would be expected by

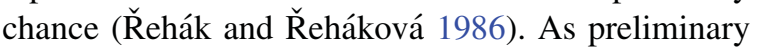
inspection of the data revealed that there is a large group of very widespread species (occurring in more than 31 of the 33 states) and another group of species that are less widespread, we tested whether these two groups differ with regard to the predominant continent of origin and life forms.

To test the effects of geographic and socioeconomic variables (zonobiome, climate scores, population density, percentage of population living in urban areas, longitude, latitude, GDP per capita) on the naturalized species richness of individual states, regression trees were applied (Breiman et al. 1984; De'ath and Fabricius 2000). To account for differences in size of the state, area was used as a weighting factor. Regression trees were constructed using binary recursive partitioning, with the default Gini-index impurity measure used as the splitting index, in CART v. 7.0 (Breiman et al. 1984; Steinberg and Colla 1995). To find an optimal tree, a sequence of nested trees of decreasing size, each being the best of all trees of its size, was produced, and their re-substitution relative errors, corresponding to residual sums of squares, were estimated. Ten-fold cross-validation was used to obtain estimates of relative errors for these trees. Following De'ath and Fabricius (2000), the most likely (modal) single minimum cost tree was chosen for description from a series of 50 cross-validation runs.

\section{Results}

Patterns of naturalized species richness across states and underlying factors

The naturalized alien vascular flora of India consists of 471 species; for 22 of them, the distribution in Indian states is unknown (Electronic Supplementary Material $3)$. In addition, there are 12 cryptogenic species with uncertain alien/native status in India (Electronic Supplementary Material 4). The analyses below are based on the 449 naturalized alien species with known distributions across the 33 states (given in Electronic Supplementary Material 2).

The number of naturalized alien species was highest in Tamil Nadu (332) and lowest in Lakshadweep (17) (Fig. 1; Table 1). The average number of naturalized species in a state is $168.8 \pm 61.4$ (mean $\pm \mathrm{SD}$ ). The average number of states per species was 12.4 , and there are 110 species that occur in 31 or more of the states.

The regression tree with the socioeconomic (human population density, population size, percentage of population living in urban areas, per capita GDP), geographic (latitude, longitude) and climate (climatic PCA axes) explanatory variables shows that the highest numbers of naturalized alien species, after accounting for differences in area, are in tropical states located below $20^{\circ}$ latitude. These tropical 


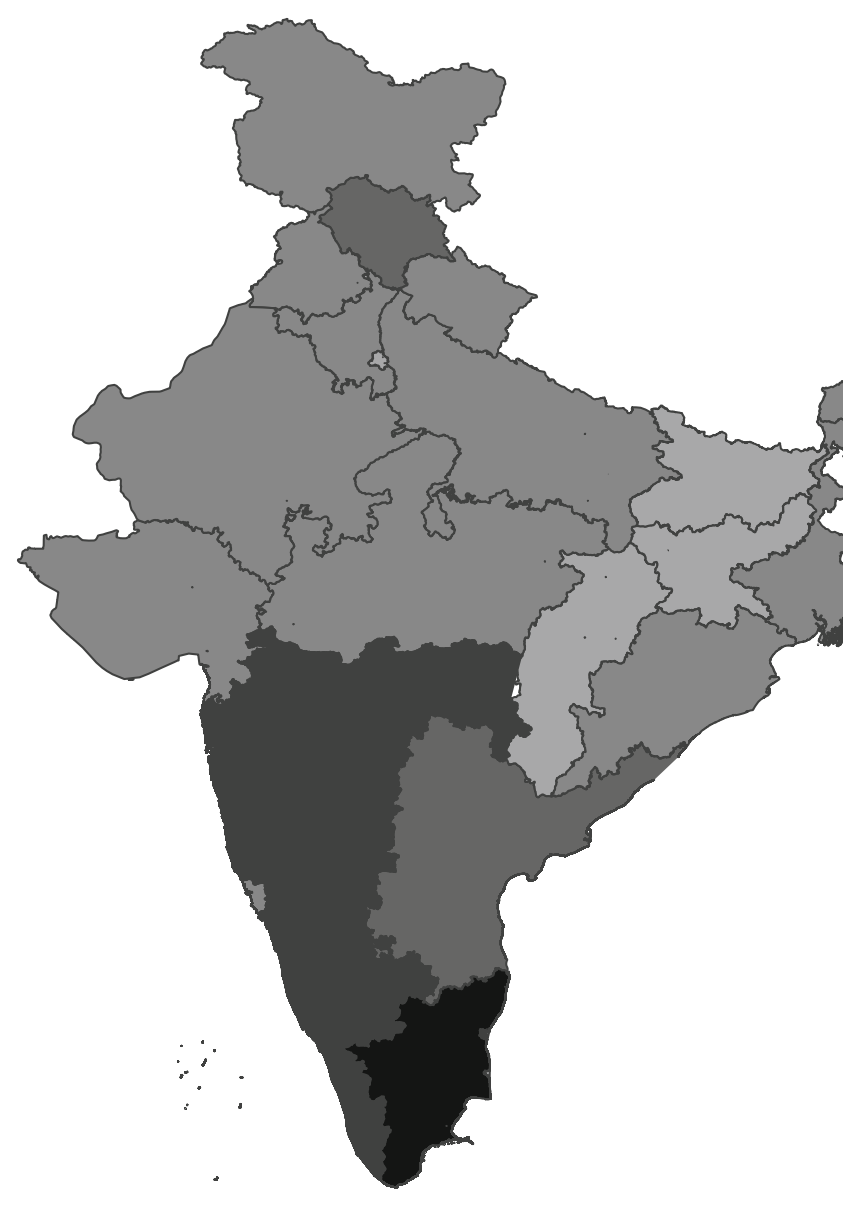

No. of naturalized species

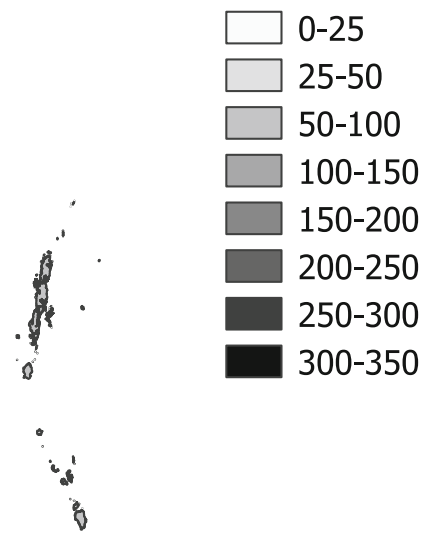

Fig. 1 Choropleth map of naturalized plant species richness in the Indian states

states harbour on average 270 naturalized alien species. In states located further to the north, those that during the driest season still have relatively high amounts of precipitation harbour more naturalized species than states with less precipitation (Fig. 2). In states with a seasonally dry climate, the number of naturalized species is fine-tuned by human population density, with a general trend towards increased naturalized species richness with increasing population density. The percentage of the population that live in urban areas and mean annual temperature (i.e. PCA axis 1) appear to be the most important surrogates at the first split, which is correlated with latitude (Fig. 2).
Composition of the naturalized flora of India: taxonomic composition, origins and life forms

The 449 species that compose the naturalized flora of Indian regions with known distribution belong to 271 genera, of which 80 genera have their representatives among the subset of 110 widespread species (i.e. the ones occurring in 31 or more states). The corresponding figures for families are 77 and 34, respectively. The number of naturalized species was highest in Compositae (75), followed by Leguminosae (60) and Poaceae (36) (Table 2). If the number of presences in states summed up over all naturalized species in a family is taken as a measure of naturalization success, the Compositae (880) and Leguminosae (727) are also the most widespread families. Some families rank higher based on the summed number of presences than 
Table 1 The numbers of naturalized species and geographic and socioeconomic characteristics of the 33 Indian states (mainly corresponding to true states and union territories (UT); see "Methods" section) used in this study*

\begin{tabular}{|c|c|c|c|c|c|c|}
\hline States/UT & $\begin{array}{l}\text { Area } \\
\left(\mathrm{km}^{2}\right)\end{array}$ & Population\# & $\begin{array}{l}\text { Population density\# (per } \\
\text { sq km) }\end{array}$ & $\begin{array}{l}\text { Urban } \\
\text { population (\%)\# }\end{array}$ & $\begin{array}{l}\text { GDP (per capita, USD) } \\
(2013-14)\end{array}$ & $\begin{array}{l}\text { No. of } \\
\text { species }\end{array}$ \\
\hline $\begin{array}{l}\text { Andaman \& } \\
\text { Nicobar }^{1}\end{array}$ & 7219 & 379,944 & 46 & 32.6 & 2395 & 96 \\
\hline Andhra Pradesh ${ }^{2}$ & 275,156 & $49,506,799$ & 308 & 29.6 & 1555 & 228 \\
\hline Arunachal Pradesh & 81,998 & $1,382,611$ & 17 & 20.8 & 1519 & 137 \\
\hline Assam & 79,091 & $31,169,272$ & 397 & 12.9 & 738 & 152 \\
\hline Bihar & 97,526 & $103,804,637$ & 1102 & 10.5 & 482 & 144 \\
\hline Chandigarh & 135 & $1,05,686$ & 9252 & 89.8 & 40,687 & 127 \\
\hline Chattisgarh & 139,989 & $25,540,196$ & 189 & 20.1 & 1057 & 121 \\
\hline Delhi & 1274 & $11,007,835$ & 11,297 & 93.2 & 5996 & 142 \\
\hline $\mathrm{Goa}^{3}$ & 4187 & $1,457,723$ & 394 & 62.2 & 4939 & 181 \\
\hline Gujarat & 185,028 & $60,383,628$ & 308 & 37.4 & 1822 & 161 \\
\hline Haryana & 44,083 & $25,353,081$ & 573 & 28.9 & 2248 & 152 \\
\hline Himachal Pradesh & 55,173 & $6,856,509$ & 123 & 9.8 & 1750 & 232 \\
\hline Jammu \& Kashmir & 106,214 & $12,548,926$ & 124 & 24.8 & 1036 & 192 \\
\hline Jharkhand & 75,640 & $32,966,238$ & 414 & 22.2 & 758 & 117 \\
\hline Karnataka & 189,305 & $61,130,704$ & 319 & 34 & 1636 & 272 \\
\hline Kerala & 38,569 & $33,387,677$ & 859 & 26 & 1737 & 290 \\
\hline Lakshadweep $^{1}$ & 38 & 64,429 & 2013 & 44.5 & 931 & 17 \\
\hline Maharashtra & 31,3051 & $112,372,972$ & 365 & 42.4 & 2225 & 283 \\
\hline Manipur & 21,738 & $2,721,756$ & 122 & 25.1 & 772 & 134 \\
\hline Madhya Pradesh & 305,278 & $72,597,565$ & 236 & 26.5 & 1033 & 151 \\
\hline Meghalaya & 22,509 & $2,964,007$ & 132 & 19.6 & 1080 & 149 \\
\hline Mizoram & 20,869 & $1,091,014$ & 52 & 49.6 & 1375 & 129 \\
\hline Nagaland & 16,649 & $1,980,602$ & 119 & 17.2 & 1313 & 134 \\
\hline Odisha & 148,981 & $41,947,358$ & 269 & 15 & 954 & 199 \\
\hline Puducherry & 558 & $1,244,464$ & 2598 & 66.6 & 2491 & 134 \\
\hline Punjab & 50,989 & $27,704,236$ & 550 & 33.9 & 1696 & 160 \\
\hline Rajasthan & 341,999 & $68,621,012$ & 201 & 23.4 & 1224 & 169 \\
\hline Sikkim & 7260 & 607,688 & 86 & 11.1 & 2962 & 157 \\
\hline Tamil Nadu & 130,124 & $72,138,958$ & 480 & 44 & 1941 & 332 \\
\hline Tripura & 10,446 & $3,671,032$ & 350 & 17.1 & 1090 & 127 \\
\hline Uttarakhand & 53,243 & $10,116,752$ & 189 & 25.7 & 1779 & 181 \\
\hline Uttar Pradesh & 241,863 & $199,581,477$ & 828 & 20.8 & 701 & 171 \\
\hline West Bengal & 85,284 & $91,347,736$ & 1029 & 28 & 1314 & 192 \\
\hline
\end{tabular}

*Data taken from various sources (see Supplementary material 1); ${ }^{\#}$ Data year 2011

${ }^{1}$ Island states

${ }^{2}$ The state of Andhra Pradesh was recently divided into Andhra Pradesh and Telangana in 2014. Both new states are considered under Andhra Pradesh

${ }^{3}$ Species from the State of Goa and Union territories (i) Daman and Diu and (ii) Dadra Nagar and Haveli were considered under Goa (see Rao 1985) 


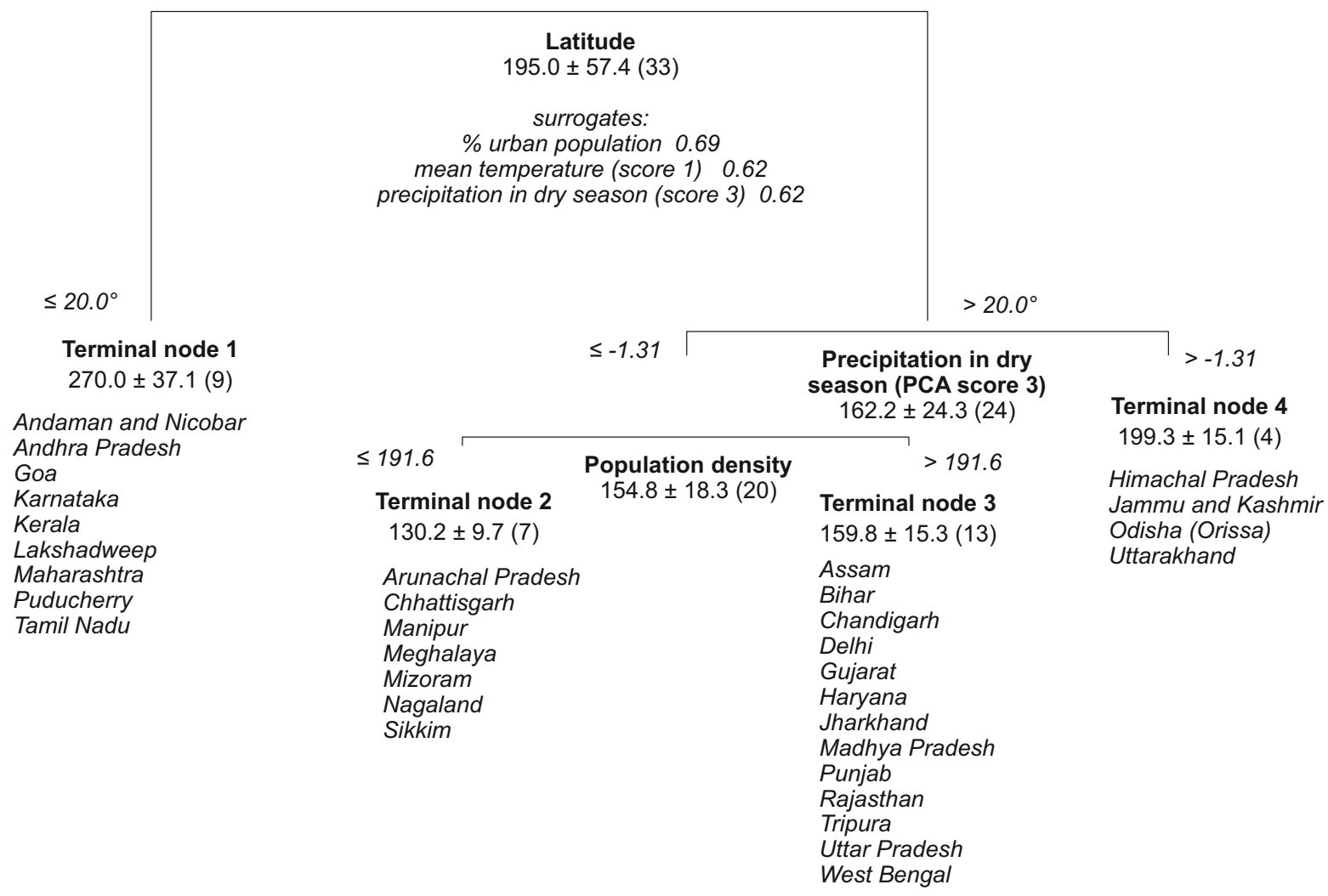

Fig. 2 Regression tree showing factors that drive the number of naturalized species in a state, weighed by its area (see Jarošík 2011). Length of the nodes represents the improvement value. The explanatory variables included are population size, human population density, percentage of urban population, latitude, longitude, per capita GDP and climatic scores derived as linear

by the species number alone: Malvaceae, Verbenaceae, Passifloraceae and Cactaceae (Table 2). On the other hand, some families that are amongst the richest in naturalized species are not represented among the widespread species (e.g. Acanthaceae, Alismataceae, Casuarinaceae, Nyctaginaceae).

Three genera are represented by 10 or more naturalized species (Solanum, Ipomoea and Euphorbia) (Table 2). The genus with the highest number of naturalized species (15) is Solanum, but the genus with the highest number in terms of the sum of presences across states is Euphorbia (235). Other genera that despite of being represented by fewer species rank quite high by the sum of presences in states are Opuntia and Alternanthera (Table 2).

To find out whether there is any pattern with regard to the continents of origin of the naturalized species and their occurrence in the Indian states, we produced combinations of bioclimatic variables that explain $83.5 \%$ of the variance of the bioclimatic data (see Dupin et al. 2011): temperature (PCA score1), precipitation in the wet and warm season (PCA score 2), and precipitation in the driest season (PCA score 3). The surrogates for the splits are shown in italics with their association values

choropleth maps for the numbers of alien species per state for each of the continents of origin (Fig. 3). Overall, the patterns are similar for most continents of origin, and show an under-representation of species of European origin (Fig. 3).

As there is a large group of species $(n=110)$ that are recorded in 31 or more states (out of 33 states) and thus are widespread across the entire territory of India (Fig. 4, Table 2), we compared this group with species occurring in fewer states $(\mathrm{n}=339$ species, on average in 6.2 states) to see if the two groups differ in terms of their origin and life history.

The widespread and less widespread species did not differ in terms of their life-form composition $\left(\chi^{2}=1.38, d f=5, p=0.927\right)$. The naturalized flora of India consists of $47.0 \%$ perennial herbs (211 taxa), $45.7 \%$ annual and biennial herbs (205), $29.2 \%$ shrubs (131), $13.4 \%$ trees (60), $11.4 \%$ climbers (51) and $2.4 \%$ 
Table 2 The most represented families and genera in the naturalized flora of India, with at least three species

\begin{tabular}{|c|c|c|c|c|c|}
\hline Families & $\begin{array}{l}\text { Number of } \\
\text { species }\end{array}$ & $\begin{array}{l}\text { Number of state } \\
\text { presences }\end{array}$ & Genera & $\begin{array}{l}\text { Number of } \\
\text { species }\end{array}$ & $\begin{array}{l}\text { Number of state } \\
\text { presences }\end{array}$ \\
\hline Compositae & 75 & 880 & Solanum & 15 & 207 \\
\hline Leguminosae & 60 & 727 & Ipomoea & 13 & 171 \\
\hline Poaceae & 36 & 324 & Euphorbia & 12 & 235 \\
\hline Solanaceae & 28 & 405 & Senna & 9 & 176 \\
\hline Euphorbiaceae & 21 & 380 & Trifolium & 7 & 35 \\
\hline Amaranthaceae & 19 & 247 & Acacia & 6 & 60 \\
\hline Convolvulaceae & 19 & 237 & Alternanthera & 6 & 127 \\
\hline Brassicaceae & 11 & 110 & Opuntia & 6 & 135 \\
\hline Lamiaceae & 11 & 122 & Oxalis & 6 & 35 \\
\hline Malvaceae & 10 & 161 & Erigeron & 5 & 40 \\
\hline Verbenaceae & 9 & 124 & Gnaphalium & 5 & 70 \\
\hline Caryophyllaceae & 8 & 78 & Oenothera & 5 & 38 \\
\hline Onagraceae & 8 & 85 & Passiflora & 5 & 75 \\
\hline Apocynaceae & 7 & 112 & Physalis & 5 & 74 \\
\hline Passifloraceae & 7 & 138 & Amaranthus & 4 & 39 \\
\hline Rubiaceae & 7 & 43 & Datura & 4 & 76 \\
\hline Cactaceae & 6 & 135 & Lepidium & 4 & 30 \\
\hline Oxalidaceae & 6 & 35 & Merremia & 4 & 23 \\
\hline Papaveraceae & 6 & 84 & Stachytarpheta & 4 & 72 \\
\hline Polygonaceae & 6 & 50 & Acmella & 3 & 45 \\
\hline Asparagaceae & 4 & 55 & Agave & 3 & 47 \\
\hline Boraginaceae & 4 & 89 & Ageratina & 3 & 16 \\
\hline Alismataceae & 3 & 10 & Argemone & 3 & 64 \\
\hline Cleomaceae & 3 & 66 & Bidens & 3 & 28 \\
\hline Iridaceae & 3 & 18 & Brachiaria & 3 & 10 \\
\hline Myrtaceae & 3 & 24 & Cleome & 3 & 66 \\
\hline Plantaginaceae & 3 & 65 & Cytisus & 3 & 12 \\
\hline Rhamnaceae & 3 & 23 & Dysphania & 3 & 14 \\
\hline Salviniaceae & 3 & 39 & Heliotropium & 3 & 80 \\
\hline
\end{tabular}

An additional measure used is the sum of recorded presences of the family or genus across all its representatives

aquatic species (11). Note that the sum of the species numbers exceeds $100 \%$, because some species belong to multiple life-form categories.

The widespread and less widespread species differed in the predominant TDWG continents of origin ( $F$ test $=8.54, d f=7, p<0.001)$. The widespread ones were represented more than expected by chance if they come from South America $(69.1 \%)$ or North America (52.7\%), and less than expected if they come from temperate Asia, tropical Asia or Europe. The less widespread species were under-represented if they come from South America, and over-represented if they come from Europe (Fig. 5).

\section{Discussion}

The naturalized alien vascular flora of India consists of 471 species, which represent $2.6 \%$ of the total plant richness of this country (18,259 species). For 22 naturalized species, there was no data on their distribution within India, and therefore the dataset analysed quantitatively in this paper was restricted to the 449 remaining species. Unlike previous studies on plant invasions in India, we present an inventory from each of 33 states (including true states and union territories), and focus on alien species that have become naturalized. 


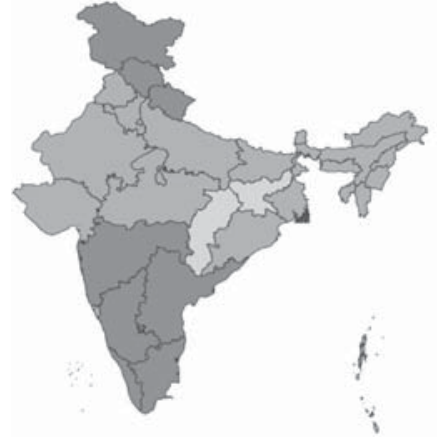

Africa

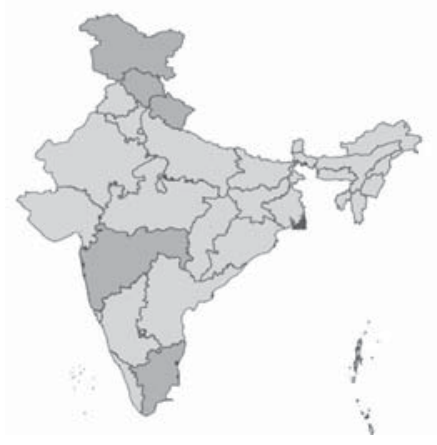

Europe

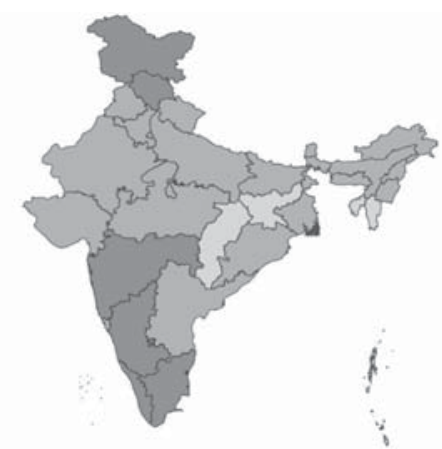

Asia temperate

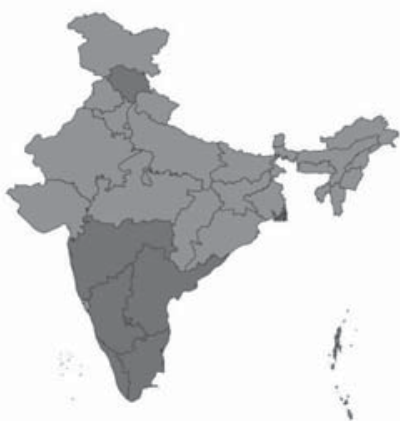

North America

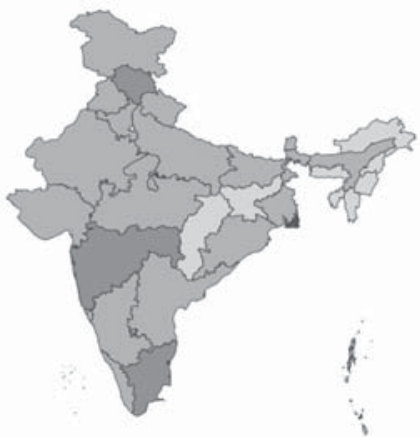

Asia tropical

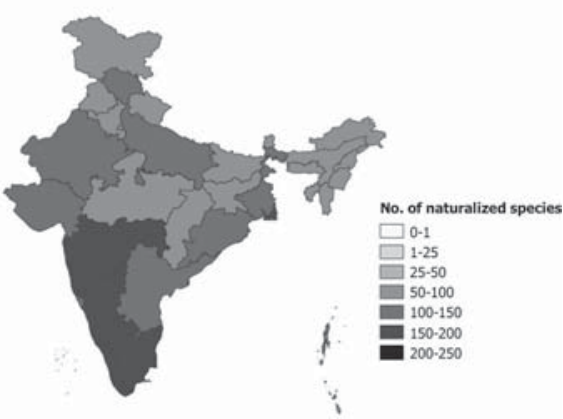

South America

Fig. 3 Choropleth maps showing the richness of naturalized species of different origin in the 33 Indian states

Fig. 4 Histogram showing the numbers of naturalized species according to the number of Indian states $(\mathrm{n}=33)$ in which they occur

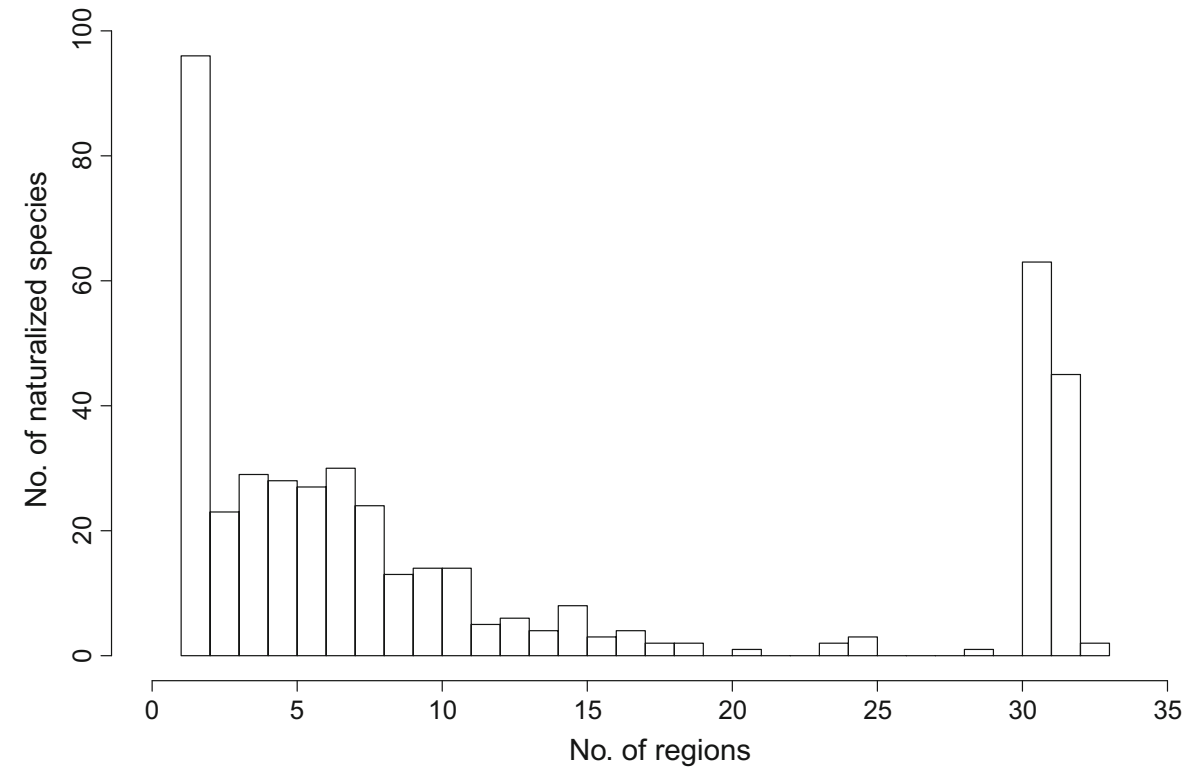

In a study on alien plants in India, Khuroo et al. (2012), report a total of 1599 alien species, but do not provide data on their distribution across the different states. Khuroo et al. (2012) classified the alien species as cultivated (812), casual (57), casual/naturalized (114), naturalized (256), naturalized/invasive (134) and invasive (225). So, after excluding the cultivated and casual species, the total number of naturalized 


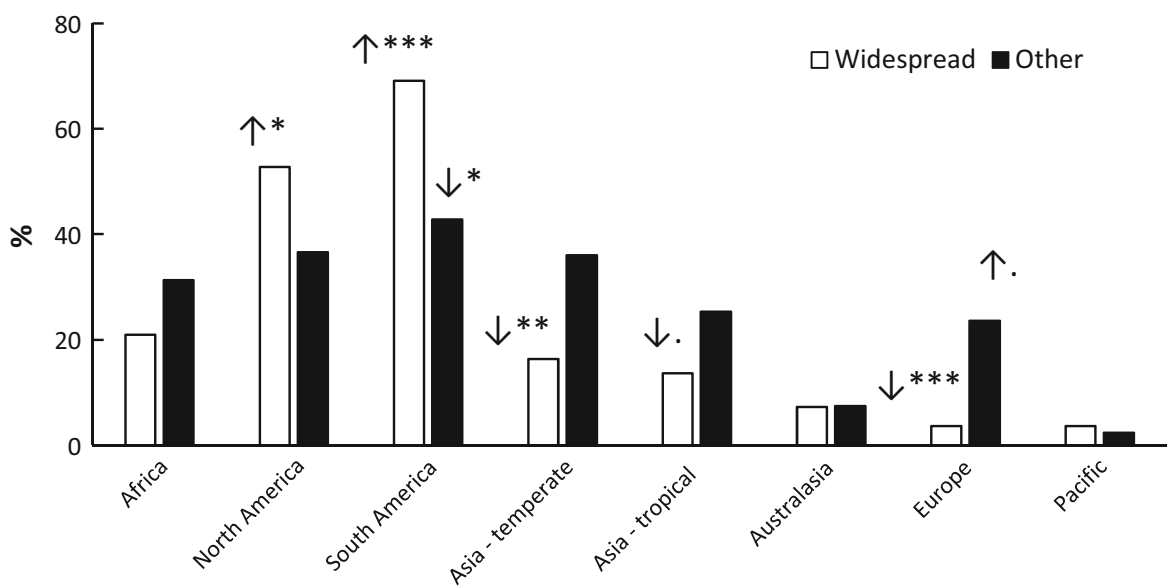

Fig. 5 Frequency distribution of the regions of origin shown separately for the group of most widespread species occurring in 31 or more Indian states (white bars), and the species occurring in fewer states (black bars). Regions that significantly differ

species previously reported for India ranges from 615 to 729 species. The number of 471 naturalized taxa in our inventory is thus considerably lower. We believe that this discrepancy is caused by the fact that for many species in India, there is contradicting evidence on their biogeographic status in earlier works. Therefore, when preparing the inventory of naturalized alien species of India, we adopted a conservative approach, and only included species for which there is good evidence that they are naturalized aliens. In the Electronic Supplementary Material 3, we provide a list of species that in some previous works have been considered naturalized but do not qualify as naturalized according to our criteria. We consider these species either as native or cultivated based on the references given in the Electronic Supplementary Material 3.

We found that the largest number of naturalized species in India belong to the Compositae (75) followed by the Leguminosae (60) (Table 2). This accords with the recent figures for invasive species in India reported by Adhikari et al. (2015). These authors found that out of 155 invasive alien plant species in India, the largest number belong to Compositae (23) followed by Leguminosae (15). Khuroo et al. (2012), on the other hand, report that the Leguminosae (178) rather than Compositae (134) had the largest number of naturalized alien species. This small discrepancy might be caused by the stricter criteria that we used for classifying a species as alien or native. Our study thus between the two groups ( $G$ test; $p<0.1, *<0.05$, ** $<0.01$, $* * *<0.001)$ are indicated by an arrow. The direction of arrows indicate over- or under-representation within the group

confirms that, as in alien floras of other countries, the Compositae family has high numbers of naturalized and invasive species (Pyšek 1997, 1998; Daehler 1998; Lambdon et al. 2008). Most likely this reflects that the Compositae is the largest dicotyledon plant family, and consequently, it is more likely that it includes many naturalized and invasive species. Pyšek et al. (2017) actually show for the global naturalized flora that although the Compositae have the largest number of naturalized species, this number is not higher than one would expect by chance, given the large total number of species in the family. Nevertheless, many of the most widely naturalized species also appear to be Compositae, with an average of $\sim 10$ Indian states per species. One reason for the naturalization success could be that many Compositae species produce a large seed crop, e.g. Ageratina adenophora, Chromolaena odorata, Mikania micrantha and Solidago gigantea (Witkowski and Wilson 2001; Tiwari et al. 2005; Mandal and Joshi 2014; Horvitz et al. 2014; Kalwij et al. 2014; Day et al. 2016).

Our data showed that the naturalized flora of India mainly consists of annual/biennial (45.7\%) and perennial herbs $(47.0 \%)$, with only few woody species (13.4\%). Herbs have short generation times, and are therefore more likely to establish and spread rapidly. Indeed some herbaceous species, such as Chromolaena odorata and Ageratina adenophora, form large populations and dominate communities in the Peechi 
area in Kerala, and the Mussoorie hills in Uttarakhand, respectively (Mangla et al. 2008; Inderjit et al. 2011). Nevertheless, there are also some woody species, such as Prosopis juliflora, that are widespread and dominate plant communities (Kaur et al. 2012).

The highest numbers of naturalized alien species were found in states that even during the driest season receive relatively high amounts of precipitation. This is in line with findings of Lambdon et al. (2008), who identified precipitation as one of the key climatic factor shaping the richness of regional alien floras in Europe. Harsh environments with low moisture or soil fertility may be less invasible because few species are adapted to such harsh environments (Zafferman et al. 2015). Ashbacher and Cleland (2015) found that increased rainfall has more positive impacts on herbaceous alien species than on native species. These authors reported that the response to the shift in rainfall pattern depends upon the relative growth of alien versus native species. Alien annual grasses suppressed native species under experimentally maintained high soil moisture (Goldstein and Suding 2014). However, differences between native and alien species in the response to water availability are not always consistent (Funk and Zachary 2010; Liu et al. 2017).

Globally, most alien plant species have naturalized in only few regions, and only few species are very widespread (Pyšek et al. 2017). In line with this, we found that most of the naturalized species occur in only few regions in India (Fig. 4). However, we also found that a remarkably large number of species are very widespread and occur in almost all states. Most of these species occurred in all 31 mainland states, but not necessarily in the island state, Lakshadweep. This indicates that these species after their introduction to the Indian subcontinent managed to spread all over the mainland. This could be because these species have a wide environmental tolerance. Interestingly, these widespread species did not differ from less widespread species with regard to life form. However, they differed to some extent with regard to their native distribution ranges; while species from South America were more frequent than expected among the widespread species, the opposite was true for species of European origin. Possibly, this reflects that the climates in India are much more similar to the ones found in South America than to the ones found in Europe.
In this paper, we provide the first state-wise inventory of naturalized alien species of India, and analyse its composition and distribution of species across the different states. Together with other such regional inventories and analyses (e.g. Arianoutsou et al. 2009; Kull et al. 2012; Khuroo et al. 2012), this contributes to a better understanding of plant naturalizations around the world (van Kleunen et al. 2015; Pyšek et al. 2017). Moreover, this inventory and analysis improve our knowledge on threats associated with plant invasions in India, and can be used to provide arguments for promoting programs on conservation of native biodiversity in the country as well as in particular states.

Acknowledgements Inderjit acknowledges support from the University of Delhi and Department of Biotechnology (BT/ PR6928/BCE/8/927/2012). PP and JP were supported by Project No. 14-36079G Centre of Excellence PLADIAS (Czech Science Foundation) and long-term research development project RVO 67985939 (The Czech Academy of Sciences). PP acknowledges the support from Praemium Academiae award from The Czech Academy of Sciences. MvK acknowledges support from the German Science Foundation (DFG; KL1866/9-1). We thank Zuzana Sixtová for technical assistance. BRPR and SS acknowledge the support from UGC (F. 19-151/2015 BSR and PDFSS-2014-15-ST-AND-9507).

Authors contribution PP, JP and MvK initiated the idea and outlined the paper; Inderjit, CRB, PS, SM, SPS, SS and BRPR collected data on species taxonomy and distributions; $\mathrm{MH}$ verified data on origin; JP analysed the data; CRB, SM and Inderjit prepared the list of species reported as alien in many previous Indian checklists that do not qualify as naturalized species; PP, MvK and Inderjit wrote the paper and all authors commented on the final draft.

\section{References}

Adhikari D, Tiwary R, Barik SK (2015) Modelling hotspots for invasive alien plants in India. PLoS ONE 10:0134665. https://doi.org/10.1371/journal.pone.0134665

Arianoutsou M, Bazos I, Delipetrou P, Kokkoris Y (2010) The alien flora of Greece: taxonomy, life traits and habitat preferences. Biol Invasions 12:3525-3549. https://doi.org/ 10.1007/s10530-010-9749-0

Ashbacher AC, Cleland EE (2015) Native and exotic plant species show differential growth but similar functional trait responses to experimental rainfall. Ecosphere 6:245. https://doi.org/10.1890/ES15-00059.1

Bhatt JR, Singh JS, Singh SP, Tripathi RS, Kohli RK (2012) Invasive alien plants: a ecological appraisal from Indian subcontinent. CABI, Wallingford

Blackburn TM, Pyšek P, Bacher S, Carlton JT, Duncan RP, Jarošík V, Wilson JR, Richardson DM (2011) A proposed 
unified framework for biological invasions. Trends Ecol Evol 26:333-339. https://doi.org/10.1016/j.tree.2011.03. 023

Blackburn TM, Essl F, Evans T, Hulme PE, Jeschke JM, Kühn I, Kumschick S, Marková Z, Mrugała A, Nentwig W, Pergl J, Pyšek P, Rabitsch W, Ricciardi A, Richardson DM, Sendek A, Vilà M, Wilson JRU, Winter M, Genovesi P, Bacher S (2014) A unified classification of alien species based on the magnitude of their environmental impacts. PLoS Biol 12:e1001850. https://doi.org/10.1371/journal.pbio. 1001850

Bogaert J, Vranken I, Anderé M (2014) Anthropogenic effects in landscapes: historical contexts and spatial pattern. In: Hong SK (ed) Biocultural landscapes. Springer, Dordrecht, pp 89-112. https://doi.org/10.1007/978-94-017-8941-7_8

Breiman L, Friedman JH, Olshen RA, Stone CG (1984) Classification and regression trees. Wadsworth International Group, Belmont

Brummitt RK (2001) World geographic scheme for recording plant distributions, 2nd edn. International Working Group on Taxonomic Databases For Plant Sciences (TDWG), Hunt Institute for Botanical Documentation, Carnegie Mellon University, Pittsburgh

Cayuela L, Stein S, Oksanen J (2017). Taxonstand: taxonomic standardization of plant species names. $\mathrm{R}$ package version 2.0. https://CRAN.R-project.org/package=Taxonstand

Corlett RT (1992) The naturalized flora of Hong Kong: a comparison with Singapore. J Biogeogr 19:421-430. https://doi.org/10.2307/2845570

Crawley MJ (1993) GLIM for ecologists. Blackwell Scientific Publications, Oxford

Daehler CC (1998) The taxonomic distribution of invasive angiosperm plants: ecological insights and comparison to agricultural weeds. Biol Conserv 84:167-180. https://doi. org/10.1016/S0006-3207(97)00096-7

Dawson W, Moser D, van Kleunen M, Kreft H, Pergl J, Pyšek P, Weigelt P, Winter M, Lenzner B, Blackburn T, Dyer E, Cassey P, Scrivens S, Economo E, Guénard B, Capinha C, Seebens H, García-Díaz P, Nentwig W, García-Berthou E, Casal C, Mandrak N, Fuller P, Meyer C, Essl F (2017) Global hotspots and correlates of alien species richness across taxonomic groups. Nat Ecol Evol 1:0186. https:// doi.org/10.1038/s41559-017-0186

Day DM, Clements DR, Gile C, Wilmot KAD, Senaratne Shen S, Weston LA, Zhang F (2016) Biology and impacts of Pacific islands invasive species. 13. Mikania micrantha Kunth (Asteraceae). Pac Sci 70:257-285. https://doi.org/ 10.2984/70.3.1

De'ath G, Fabricius KE (2000) Classification and regression trees: a powerful yet simple technique for ecological data analysis. Ecology 81:3178-3192. https://doi.org/10.1890/ 0012-9658(2000)081[3178:CARTAP]2.0.CO;2

Dupin M, Reynaud P, Jarošík V, Baker R, Brunel S, Eyre D, Pergl J, Makowski D (2011) Effects of the training dataset characteristics on the performance of nine species distribution models: application to Diabrotica virgifera virgifera. PLoS ONE 6:e20957. https://doi.org/10.1371/ journal.pone.0020957

Early R, Bradley BA, Dukes JS, Lawler JJ, Olden JD, Blumenthal DM, Gonzalez P, Grosholz ED, Ibañez I, Miller LP, Sorte CJB, Tatem AJ (2016) Global threats from invasive alien species in the twenty-first centuary and national response capacities. Nat Commun 7:12485. https://doi.org/10.1038/ncomms 12485

Essl F, Rabitsch W (eds) (2002) Neobiota in Österreich. Umweltbundesamt GmbH, Wien

Funk JL, Zachary VA (2010) Physiological responses to shortterm water and light stress in native and invasive plant species in southern California. Biol Invasions 12:1685-1694. https://doi.org/10.1007/s10530-009-95816

Goldstein L, Suding K (2014) Intra-annual rainfall regime shifts competitive interactions between coastal sage scrub and invasive grasses. Ecology 95:425-435. https://doi.org/10. 1890/12-0651.1

Hijmans RJ, Cameron SE, Parra JL, Jones PG, Jarvis A (2005) Very high resolution interpolated climate surfaces for global land areas. Int J Climatol 25:1965-1978. https://doi. org/10.1002/joc. 1276

Horvitz N, Wang R, Zhu M, Wan FH, Nathan R (2014) A simple modeling approach to elucidate the main transport processes and predict invasive spread: river-mediated invasion of Ageratina adenophora in China. Water Resour Res 50:9738-9747. https://doi.org/10.1002/2014WR015537

Hulme PE (2009) Trade, transport and trouble: managing invasive species pathways in an era of globalization. Biol Invasions 46:10-18. https://doi.org/10.1111/j.1365-2664. 2008.01600.x

Hulme PE, Pyšek P, Nentwig W, Vilà M (2009) Will threat of biological invasions unite the European Union? Science 324:40-41. https://doi.org/10.1126/science.1171111

Inderjit, Evans H, Crocoll C, Bajpai D, Kaur R, Feng Y, Silva C, Carreón JT, Valiente-Banuet A, Gershenzon J, Callaway RM (2011) Volatile chemicals from leaf litter are associated with invasiveness of a neotropical weed in Asia. Ecology 92:316-324. https://doi.org/10.1890/10-0400.1

IndianStat (2017) Formatted numbers of India. Galitein Technologies, Gujarat. http://www.indianstat.in. Accessed 2016

Iqbal MC, Wijesundra DSA, Ranwala SMW (2014) Climate change, invasive alien flora and concerns for their Management in Sri Lanka. Ceylon J Sci 43:1-15. https://doi. org/10.4038/cjsbs.v43i2.7321

Jarošík V (2011) Cart and related methods. In: Simberloff D, Rájmanek M (eds) Encyclopedia of biological invasions. University of California Press, Berkeley, pp 104-108

Jiang H, Fan Q, Li JT, Shi S, Li SP, Liao WB, Shu WS (2011) Naturalization of alien plants in China. Biodiv Conserv 20:1545-1556. https://doi.org/10.1007/s10531-011-0044-

Kalwij JM, Steyn C, le Rouxc PC (2014) Repeated monitoring as an effective early detection means: first records of naturalised Solidago gigantea Aiton (Asteraceae) in southern Africa. S Afr J Bot 93:204-206. https://doi.org/10.1016/j. sajb.2014.04.013

Kaur R, Gonzáles WL, Llambi LD, Soriano PJ, Callaway RM, Rout ME, Gallaher TJ, Inderjit (2012) Community impacts of Prosopis juliflora invasion: biogeographic and congeneric comparisons. PLoS ONE 7:e44966. https://doi.org/ 10.1371/journal.pone.0044966

Kettunen M, Genovesi P, Gollasch S, Pagad S, Starfinger U, ten Brink P, Shine C (2009) Technical support to EU strategy on invasive species (IAS) - assessment of the impacts of 
IAS in Europe and the EU (final module report for the European Commission). Institute for European Environmental Policy (IEEP), Brussels, Belgium

Khuroo AA, Reshi ZA, Malik AH, Weber E, Rashid I, Dar GH (2012) Alien flora of India: taxonomic composition, invasion status and biogeographic affiliations. Biol Invasions 14:99-113. https://doi.org/10.1007/s10530-011-9981-2

Kull CA, Tassin J, Moreau S, Ramiarantsoa HR, Blanc-Pamard C, Carriere SM (2012) The introduced flora of Madagascar. Biol Invasions 14:875-888. https://doi.org/10.1007/ s10530-011-0124-6

Kumschick S, Bacher S, Evans T, Marková Z, Pergl J, Pyšek P, Vaes-Petignat $S$, van der Veer $G$, Vilà $M$, Nentwig W (2015) Comparing impacts of alien plants and animals using a standard scoring system. J Appl Ecol 52:552-561. https://doi.org/10.1111/1365-2664.12427

Lambdon PW, Pyšek P, Basnou C, Hejda M, Arianoutsou M, Essl F, Jarošík V, Pergl J, Winter M, Anastasiu P, Andriopoulos P, Bazos I, Brundu G, Celesti-Grapow L, Chassot P, Delipetrou P, Josefsson M, Kark S, Klotz S, Kokkoris Y, Kühn I, Marchante H, Perglová I, Pino J, Vilà M, Zikos A, Roy D, Hulme PE (2008) Alien flora of Europe: species diversity, temporal trends, geographical patterns and research needs. Preslia 80:101-149

Liu J, Dong M, Miao SL, Li ZY, Song MH, Wong RQ (2006) Invasive alien plants in China: role of clonality and geographical comparisons. Biol Invasions 8:1461-1470. https://doi.org/10.1007/s10530-005-5838-x

Liu Y, Oduor AMO, Zhang Z, Manea A, Tooth IM, Leishman MR, Xu X, van Kleunen M (2017) Do invasive alien plants benefit more from global environmental change than native plants? Glob Change Biol. https://doi.org/10.1111/gcb. 13579

Mandal G, Joshi SP (2014) Invasion establishment and habitat suitability of Chromolaena odorata (L.) King and Robinson over time and space in the western Himalayan forests of India. J Asia Pac Biodivers 7:391-400. https://doi.org/ 10.1016/j.japb.2014.09.002

Mangla S, Inderjit, Callaway RM (2008) Exotic invasive plant accumulates native soil pathogens which inhibit native plants. J Ecol 96:58-67. https://doi.org/10.1111/j.13652745.2007.01312.x

McGeoch MA, Butchart SHM, Spear D, Marais E, Kleynhans EJ, Symes A, Chanson J, Hoffmann M (2010) Global indicators of biological invasion: species numbers, biodiversity impact and policy responses. Divers Distrib 16:95-108. https://doi.org/10.1111/j.1472-4642.2009. 00633.x

Medvecká J, Kliment J, Májeková J, Halada L', Zaliberová M, Gojdičová E, Feráková V, Jarolímek I (2012) Inventory of the alien flora of Slovakia. Preslia 84:257-310

Millenium Ecosystem Assessment (2005) Ecosystems and human well-being: synthesis. Island Press, Washington

NITI Aayog (2015) GSDP at current prices, 2004-2005 series (2004-05 to 2014-15). National Institution for Transforming India. https://niti.gov.in/content/gsdp-current-prices2004-05-series-2004-05-2014-15

Paschou P, Drineas P, Yannaki E, Razou A, Kanaki K, Tsetsos F, Padmanabhuni SS, Michalodimitrakis M, Renda MC, Pavlovic S, Anagnostopoulos A, Stamatoyannopoulos JA, Kidd KA, Stamatoyannopoulos G (2014) Maritime route of colonization of Europe. Proc Natl Acad Sci USA 25:9211-9216. https://doi.org/10.1073/pnas.1320811111

Pyšek P (1997) Compositae as invaders: better than the others? Preslia 69:9-22

Pyšek P (1998) Is there a taxonomic pattern to plant invasions? Oikos 82:282-294. https://doi.org/10.2307/3546968

Pyšek P, Sádlo J, Mandák B (2002) Catalogue of alien plants of the Czech Republic. Preslia 74:97-186

Pyšek P, Richardson DM, Rejmánek M, Webster G, Williamson M, Kirschner J (2004) Alien plants in checklists and floras: towards better communication between taxonomists and ecologists. Taxon 53:131-143

Pyšek P, Danihelka J, Sádlo J, Chrtek J Jr, Chytrý M, Jarošík V, Kaplan Z, Krahulec F, Moravcová L, Pergl J, Štajerová K, Tichý L (2012a) Catalogue of alien plants of the Czech Republic, 2nd edn.: checklist update, taxonomic diversity and invasion patterns. Preslia 84:155-255

Pyšek P, Jarošík V, Hulme PE, Pergl J, Hejda M, Schaffner U, Vilà M (2012b) A global assessment of invasive plant impacts on resident species, communities and ecosystems: the interaction of impact measures, invading species' traits and environment. Glob Change Biol 18:1725-1737. https://doi.org/10.1111/j.1365-2486.2011.02636.x

Pyšek P, Pergl J, Essl F, Lenzner B, Dawson W, Kreft H, Weigelt P, Winter M, Kartesz J, Nishino M, Antonova LA, Barcelona JF, Cabezas FJ, Cárdenas D, Cárdenas-Toro J, Castaño N, Chacón E, Chatelain C, Dullinger S, Ebel AL, Figueiredo E, Fuentes N, Genovesi P, Groom QJ, Henderson L, Inderjit, Kupriyanov A, Masciadri S, Maurel N, Meerman J, Morozova O, Moser D, Nickrent D, Nowak PM, Pagad S, Patzelt A, Pelser PB, Schulze M, Seebens H, Shu W, Thomas J, Velayos M, Weber E, Wieringa JJ, Baptiste MP, van Kleunen M (2017) Naturalized alien flora of the world: species diversity, taxonomic and phylogenetic patterns, geographic distribution and global hotspots of plant invasion. Preslia 89:203-274

R Core Team (2016). R: a language and environment for statistical computing. R Foundation for Statistical Computing, Vienna, Austria. https://www.R-project.org/

Rao RS (1985) Flora of Goa, Diu, Daman, Dadra and Nagar Haveli, vol 1. Botanical Survey of India, Kolkata

Reddy CS, Bagyanarayana G, Reddy KN, Raju VS (2008) Invasive alien flora of India. National Biological Infrastructure, US Geological Survey, USA

Řehák J, Řeháková B (1986) Analýza kategorizovaných dat v sociologii. Academia, Prague (in Czech)

Richardson DM, Pyšek P, Rejmánek M, Barbour MG, Panetta FD, West CJ (2000) Naturalization and invasion of alien species: concepts and definitions. Divers Distrib 6:93-107. https://doi.org/10.1046/j.1472-4642.2000.00083.x

Rumlerová Z, Vilà M, Pergl J, Nentwig W, Pyšek P (2016) Scoring environmental and socioeconomic impacts of alien plants invasive in Europe. Biol Invasions 18:3697-3711. https://doi.org/10.1007/s10530-016-1259-2

Seebens H, Essl F, Dawson W, Fuentes N, Moser D, Perg J, Pyšek P, van Kleunen M, Weber E, Winter M, Blasius B (2015) Global trade will accelerate plant invasions in emerging economies under climate change. Glob Change Biol 21:4128-4140. https://doi.org/10.1111/gcb.13021

Shrestha BB (2016) Invasive alien plant species in Nepal. In: Jha PK, Siwakoti M, Rajbhandary S (eds) Frontiers of botany. 
Central Department of Botany, Tribhuvan University, Kathmandu, pp 269-284

Steinberg G, Colla P (1995) CART: Tree-structured non-parametric data analysis. Salford Systems, San Diego

Tiwari S, Adhikari B, Siwakoti M, Subedi K (2005) An inventory and assessment of invasive alien plant species of Nepal. IUCN-The World Conservation Union, Nepal, p 116

van Kleunen M, Dawson W, Essl F, Pergl J, Winter M, Weber E, Kreft H, Weigelt P, Kartesz J, Nishino J, Antonova LA, Barcelona JF, Cabezas FJ, Cárdenas D, Cárdenas-Toro J, Castaño N, Chacón E, Chatelain C, Ebel AL, Figueiredo E, Fuentes N, Groom QJ, Henderson L, Inderjit, Kupriyanov A, Masciadri S, Meerman J, Morozova O, Mose D, Nickrent D, Patzelt A, Pelser PB, Baptiste MP, Poopath Schulze M, Seebens H, Shu W, Thomas J, Velayos M, Wieringa JJ, Pyšek P (2015) Global exchange and accumulation of nonnative species. Nature 525:100-103. https://doi.org/10. 1038/nature 14910

Vilà M, Basnou C, Pyšek P, Josefsson M, Genovesi P, Gollasch S, Nentwig W, Olenin S, Roques A, Roy D, Hulme PE, DAISIE Partners (2010) How well do we understand the impacts of alien species on ecosystem services? A panEuropean cross-taxa assessment. Front Ecol Environ 8:135-144. https://doi.org/10.1890/080083

Vilà M, Rohr RP, Espinar JL, Hulme PP, Pergl J, Schaffner U, Le Roux J, Pyšek P (2015) Explaining the variation in impacts of non-native plants on local-scale species richness: the role of phylogenetic relatedness. Glob Ecol Biogeogr 24:139-146. https://doi.org/10.1111/geb.12249
Witkowski ETF, Wilson M (2001) Changes in density, biomass, seed production and soil seed banks of the non-native invasive plant, Chromolaena odorata, along a 15 year chronosequence. Plant Ecol 152:13-27. https://doi.org/10. 1023/A:1011409004004

Wu SH, Wang HH (2005) Potential Asteraceae invaders in Taiwan: insights from the flora and herbarium records of casual and naturalized alien species. Taiwania 50:62-70

Wu S-H, Chaw S-M, Rejmánek M (2003) Naturalized Fabacease (Leguminosae) species in Taiwan: the first approximation. Bot Bull Acad Sin 44:59-66

Wu S-H, Hsieh C-F, Rejmánek M (2004a) Catalogue of the naturalized flora of Taiwan. Taiwania 49:16-31

Wu S-H, Rejmánek M, Hsieh C-F, Chaw S-M (2004b) Plant invasions in Taiwan: insights from the flora of casual and naturalized alien species. Divers Distrib 10:349-362. https://doi.org/10.1111/j.1366-9516.2004.00121.x

Wu SH, Sun HT, Teng YC, Rejmánek M, Chaw SM, Yang TYA, Hsieh CF (2010) Patterns of plant invasion in China: taxonomic, biogeographic, climatic approaches and anthropogenic effects. Biol Invasions 12:2179-2206. https://doi.org/10.1007/s10530-009-9620-3

Zafferman E, Stevens JT, Charles GK, Dunbar-Irwin M, Emam T, Fick S, Morales LV, Walf KM, Young DJN, Young TP (2015) Plant communities in harsh sites are less invaded: a summary of observations and proposed explanations. AoB Plants 7:plv056. https://doi.org/10.1093/aobpla/plv056 